\title{
THE EFFECT OF GAMMA IRRADIATION ON THE SEX RATIO OF MELANDRIUM SPECIES
}

\author{
D. R. DAVIES and E. T. WALL \\ Wantage Research Laboratory, Atomic Energy Research Establishment
}

Received 24.i.61

THE data available on the effect of ionising radiations on sex ratios in higher organisms are conflicting. Early work with Drosophila showed that the sex ratio tended to change in favour of males (reviewed by Catcheside and Lea, I945), and Schull and Neel (1955) concluded that there was a significant increase in the number of males in the progenies of human males exposed to the Japanese explosions. However, with mice exposed to doses of up to Iooo rads in both the pre- and post-sterile periods there was no significant change in the sex ratio of their progenies (Hertwig, I938; Russell, I954; Kohn, I96o). In the present experiment we have studied the effect of gamma radiation on the sex ratio of progenies of Melandrium species. These are dioecious species having an X-Y sex mechanism, a heterogametic male sex and heteromorphic sex chromosomes, the $Y$ being longer than the $\mathbf{X}$ and having a definite male influence.

\section{MATERIALS AND METHODS}

Three populations of Melandrium album ( $\mathrm{La} 6,8$ and 9) and one of $M$. rubrum ( $L a 3$ ) were used, one male plant and two females being chosen at random from each population. Two flowers on each female plant were pollinated with pollen from the selected male parent of that population. Mature pollen was exposed to one of the following doses of $\gamma$-rays, at a rate of 25 rads per minute-25, 100, 400, 1600 and 6400 rads, and used immediately afterwards for pollination of the female flowers. Control pollinations were also made in all instances. Care was taken to ensure that all pollinations were as uniform as possible-all being massive pollinations of the base of the styles. This was important in view of the known differential growth rates of $X$ and $Y$ bearing pollen tubes. All progenies were space planted in boxes maintained initially in the greenhouse and later outdoors.

\section{RESULTS}

Details of percentage germination and percentage females are given in tables I-4. No correlation existed between these two percentages $\left(t_{10}=\mathrm{I} \cdot 6 \mathrm{I}_{5} ; \mathrm{P}=0.2\right.$ to $\left.0 \cdot \mathrm{I}\right)$. The populations differed in terms of the percentage females and differences also occurred between genotypes within populations (table 5). In most instances there was a tendency for an increase in the proportion of females with increasing dose. This increase was not linear-a proportionally greater one occurring at lower doses, followed in several instances by a drop and a further later increase (see table 5 " within irradiated"). Control progenies differed 
TABLE 1

\begin{tabular}{|c|c|c|c|}
\hline $\begin{array}{l}\text { Dose in } \\
\text { rads }\end{array}$ & Seeds & $\underset{\%}{\text { Germination }}$ & $\begin{array}{c}\text { Females } \\
\text { in progeny } \\
\%\end{array}$ \\
\hline \multicolumn{4}{|c|}{$\operatorname{Lag}_{9}(2) \times \operatorname{Lag}(4)$} \\
\hline $\begin{array}{r}0 \\
25 \\
100 \\
400 \\
1600 \\
6400\end{array}$ & $\begin{array}{l}626 \\
621 \\
580 \\
892 \\
726 \\
721\end{array}$ & $\begin{array}{r}19.0 \\
21 \cdot 4 \\
54.8 \\
5 \cdot 8 \\
10 \cdot 9 \\
21 \cdot 1\end{array}$ & $\begin{array}{l}30 \cdot 3 \\
51 \cdot 5 \\
58 \cdot 9 \\
42 \cdot 3 \\
39 \cdot 2 \\
61 \cdot 8\end{array}$ \\
\hline \multicolumn{4}{|c|}{$\operatorname{Lag}(3) \times \operatorname{Lag}(4)$} \\
\hline $\begin{array}{r}0 \\
25 \\
100 \\
400 \\
1600 \\
6400\end{array}$ & $\begin{array}{l}444 \\
347 \\
5^{0} 7 \\
57^{2} \\
507 \\
282\end{array}$ & $\begin{array}{l}25 \cdot 2 \\
70 \cdot 0 \\
28 \cdot 2 \\
54 \cdot 0 \\
48 \cdot 7 \\
34 \cdot 0\end{array}$ & $\begin{array}{l}59 \cdot 8 \\
64 \cdot 6 \\
65 \cdot 7 \\
58 \cdot 6 \\
58 \cdot 7 \\
77 \cdot 0\end{array}$ \\
\hline
\end{tabular}

TABLE 2

\begin{tabular}{|c|c|c|c|}
\hline $\begin{array}{l}\text { Dose in } \\
\text { rads }\end{array}$ & Seeds & $\begin{array}{c}\text { Germination } \\
\%\end{array}$ & $\begin{array}{c}\text { Females } \\
\text { in progeny } \\
\%\end{array}$ \\
\hline \multicolumn{4}{|c|}{$\operatorname{La} 6(3) \times \operatorname{La} 6(4)$} \\
\hline $\begin{array}{r}0 \\
25 \\
100 \\
400 \\
1600 \\
6400\end{array}$ & $\begin{array}{l}403 \\
108 \\
409 \\
429 \\
55^{1} \\
475\end{array}$ & $\begin{array}{l}28 \cdot 0 \\
57 \cdot 4 \\
74 \cdot 6 \\
35 \cdot 4 \\
35 \cdot 0 \\
20 \cdot 0\end{array}$ & $\begin{array}{l}84 \cdot 6 \\
83 \cdot 3 \\
79 \cdot 8 \\
75 \cdot 4 \\
61 \cdot 6 \\
80 \cdot 9\end{array}$ \\
\hline \multicolumn{4}{|c|}{$\operatorname{La} 6(I) \times \operatorname{La} 6(4)$} \\
\hline $\begin{array}{r}0 \\
25 \\
100 \\
400 \\
1600 \\
6400\end{array}$ & $\begin{array}{l}527 \\
473 \\
474 \\
444 \\
470 \\
480\end{array}$ & $\begin{array}{l}38 \cdot 7 \\
85 \cdot 8 \\
39 \cdot 7 \\
18 \cdot 7 \\
31 \cdot 1 \\
26 \cdot 0\end{array}$ & $\begin{array}{l}75 \cdot 5 \\
77 \cdot 2 \\
67 \cdot 6 \\
77 \cdot 2 \\
81 \cdot 9 \\
80 \cdot 6\end{array}$ \\
\hline
\end{tabular}


TABLE $_{3}$

\begin{tabular}{|c|c|c|c|}
\hline $\begin{array}{l}\text { Dose in } \\
\text { rads }\end{array}$ & Seeds & $\underset{\%}{\text { Germination }}$ & $\begin{array}{c}\text { Females } \\
\text { in progeny } \\
\%\end{array}$ \\
\hline \multicolumn{4}{|c|}{$\operatorname{La} 8(2) \times \operatorname{La} 8(I)$} \\
\hline $\begin{array}{r}0 \\
25 \\
100 \\
400 \\
1600 \\
6400\end{array}$ & $\begin{array}{l}590 \\
514 \\
365 \\
502 \\
636 \\
533\end{array}$ & $\begin{array}{l}38 \cdot 8 \\
32 \cdot 5 \\
40 \cdot 0 \\
33 \cdot 3 \\
26 \cdot 9 \\
34 \cdot 7\end{array}$ & $\begin{array}{l}71 \cdot 9 \\
76 \cdot 7 \\
85 \cdot 5 \\
75 \cdot 7 \\
73 \cdot 7 \\
77 \cdot 6\end{array}$ \\
\hline \multicolumn{4}{|c|}{$\operatorname{La} 8(4) \times \operatorname{La} 8(I)$} \\
\hline $\begin{array}{r}0 \\
25 \\
100 \\
400 \\
1600 \\
6400\end{array}$ & $\begin{array}{l}488 \\
622 \\
35^{8} \\
397 \\
494 \\
207\end{array}$ & $\begin{array}{r}11 \cdot 3 \\
13.3 \\
13.7 \\
15.6 \\
9.1 \\
23.2\end{array}$ & $\begin{array}{l}58 \cdot 8 \\
68 \cdot 1 \\
82 \cdot 1 \\
85 \cdot 3 \\
78 \cdot 8 \\
80 \cdot 0\end{array}$ \\
\hline
\end{tabular}

TABLE $_{4}$

\begin{tabular}{|c|c|c|c|}
\hline $\begin{array}{l}\text { Dose in } \\
\text { rads }\end{array}$ & Seeds & $\underset{\%}{\text { Germination }}$ & $\begin{array}{c}\text { Females } \\
\text { in progeny } \\
\%\end{array}$ \\
\hline \multicolumn{4}{|c|}{$\operatorname{La}_{3}(3) \times \operatorname{La~}_{3}(I)$} \\
\hline $\begin{array}{r}0 \\
25 \\
100 \\
400 \\
1600 \\
6400\end{array}$ & $\begin{array}{l}597 \\
622 \\
525 \\
518 \\
493 \\
549\end{array}$ & $\begin{array}{l}42 \cdot 2 \\
31 \cdot 8 \\
56 \cdot 6 \\
48 \cdot 8 \\
51 \cdot 1 \\
29 \cdot 5\end{array}$ & $\begin{array}{l}52 \cdot 4 \\
55 \cdot 0 \\
58 \cdot 1 \\
58 \cdot 9 \\
56 \cdot 8 \\
62 \cdot 4\end{array}$ \\
\hline \multicolumn{4}{|c|}{ 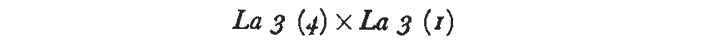 } \\
\hline $\begin{array}{r}0 \\
25 \\
100 \\
400 \\
1600 \\
6400\end{array}$ & $\begin{array}{l}482 \\
465 \\
127 \\
447 \\
434 \\
430\end{array}$ & $\begin{array}{l}42 \cdot 3 \\
54 \cdot 6 \\
55 \cdot 9 \\
46 \cdot 5 \\
43 \cdot 8 \\
49 \cdot 1\end{array}$ & $\begin{array}{l}52 \cdot 2 \\
54 \cdot 7 \\
57 \cdot 4 \\
54 \cdot 3 \\
58 \cdot 4 \\
62 \cdot 3\end{array}$ \\
\hline
\end{tabular}


TABLE 5

Analysis of variance for sex-ratio (per cent. females transformed to angles)

\begin{tabular}{|c|c|c|c|c|c|}
\hline Item & & M.S. & N. & V.R. & P. \\
\hline $\begin{array}{l}\text { Doses } \\
\text { (i) Control v. irradiated } \\
\text { (ii) Within irradiated } \\
\text { Populations } \\
\text { Within populations : } \\
\text { Populations } \times \text { dose } \\
\text { Residual }\end{array}$ & $\begin{array}{ll}: & : \\
: & : \\
: & : \\
: & :\end{array}$ & $\begin{array}{r}115.79 \\
163.50 \\
107.65 \\
1209.83 \\
179.91 \\
42 \cdot 32 \\
29.88\end{array}$ & $\begin{array}{r}5 \\
1 \\
4 \\
3 \\
4 \\
15 \\
65\end{array}$ & $\begin{array}{l}3 \cdot 875 \\
5 \cdot 472 \\
3 \cdot 603 \\
6 \cdot 725 \\
6 \cdot 021 \\
1 \cdot 416 \\
\cdots\end{array}$ & $\begin{array}{l}0 \cdot 01-0 \cdot 001 \\
0 \cdot 02-0 \cdot 01 \\
0 \cdot 02-0 \cdot 01 \\
0.05-0.02 \\
<\cdot 001 \\
\text { N.S. } \\
\quad \ldots\end{array}$ \\
\hline
\end{tabular}

significantly from irradiated progenies, but no dose $\times$ population or dose $\times$ within population interaction existed. The last two items were bulked with replicate differences as the error component in the analysis. Since all populations responded in a similar manner, the data were bulked and the overall means are plotted against dose in fig. I.

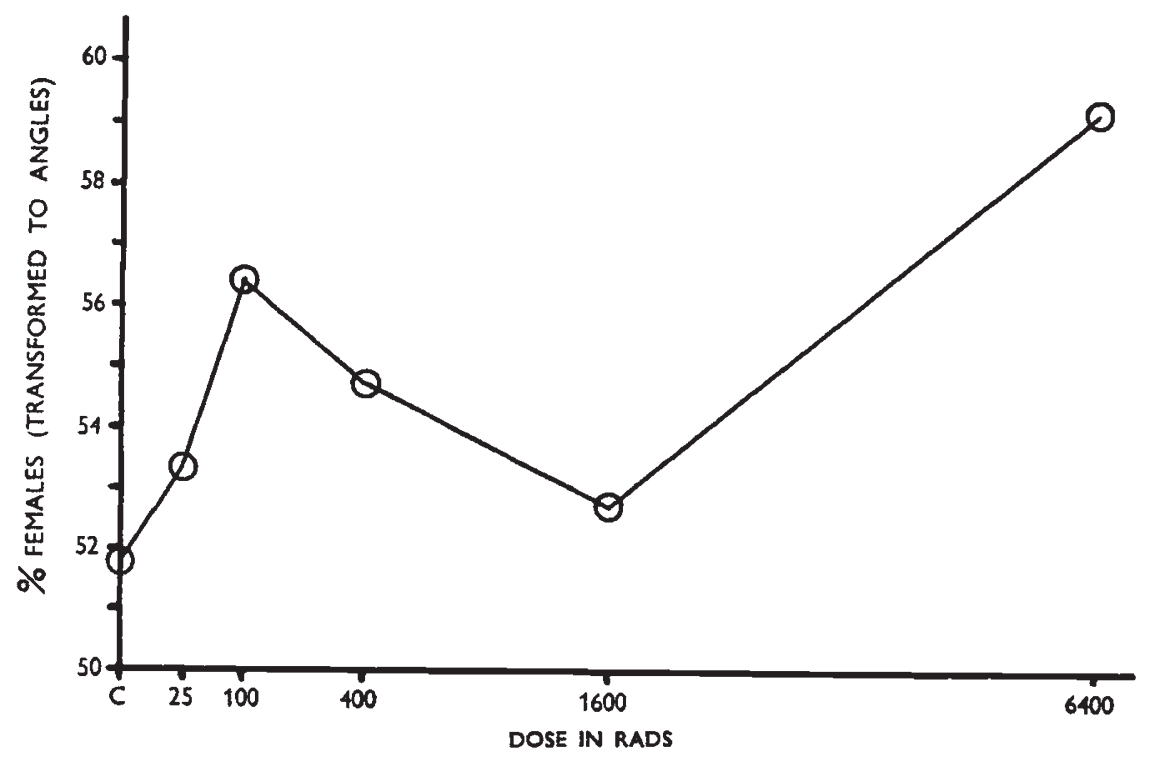

Frc. 1.-The effect of pollen irradiation on the sex ratio of Melandrium progenies.

\section{DISCUSSION}

A genetic control of sex ratio in Melandrium species has been demonstrated by Lawrence (1959), and the between and within population differences observed in the present instance may be understood in these terms. The magnitude of the differences in sex ratio was as great in some instances within as between populations. After exposing mature pollen to gamma rays an overall increase occurred in the percentage of female progeny surviving to maturity. This increase was marked at the lowest doses and could be attributed to physiological changes induced in the pollen grains which resulted in a more rapid 
growth of X-bearing pollen tubes. These are known to have a faster growth rate than Y-bearing ones, and this natural advantage may have been enhanced by low doses of radiation. Such a stimulation of pollen tube growth has been reported by other workers (Swaminathan and Murty, 1959). At higher doses this presumably has not occurred, but another effect has been produced by the radiation involving the greater induction of lethality in male embryos. This may be understood in terms of the induction of lethal mutations in the sex chromosomes. In Melandrium the $\mathrm{Y}$ is longer than the $\mathrm{X}$, and is physiologically active (Westergaard, I958). It should therefore be as susceptible as the $\mathrm{X}$ per unit length of chromosome to the induction of dominant and recessive lethal types of injury. More dominant and recessive lethals would therefore be produced in the $\mathrm{Y}$ than the $\mathrm{X}$. The former factor, dominant lethality, would lead to a greater lethality of male progeny as also would the latter as some recessive lethals would be expressed in the heterogametic sex.

These results do not agree with those obtained from analyses of mice, human, and Drosophila populations. With the last, an increase in males occurred, whereas with the first of these species no change in sex ratio has been observed after radiation exposures and the significance of the differences quoted by Schull and Neel (loc. cit.) between irradiated and control human populations has been queried by Kohn (loc. cit.). He has also contested the theoretical basis of their argument that an increase in the number of males might have been expected on the basis of the physiological inertness of the human $\mathrm{Y}$ chromosome, and hence its lack of susceptibility to a dominant lethal type of injury. Recent evidence would argue against such inertness of the Y (Jacobs and Strong, 1959; Ford, Polani, Briggs and Bishop, 1959). Some explanation of the variations in the response of different species may be found in the relative activities and sizes of the sex chromosomes. Humans and mice have a $\mathrm{Y}$ chromosome which is active, having a positive masculine effect, but which is smaller than the $\mathrm{X}$. Because of this size difference, more dominant lethals should be produced in the $\mathrm{X}$ chromosome and an increase in males should occur. Recessive lethals would be unimportant here as we assume that they would not be expressed in the heterogametic sex. In Drosophila the $\mathrm{Y}$ is longer than the $\mathrm{X}$, and on the basis of length more dominant and recessive lethality would be expected in the $\mathrm{Y}$ and hence more females would be expected in the progeny. However, the $\mathrm{Y}$ is considered to be relatively inert and less prone to this form of injury, and hence more males are found in the progeny of irradiated males. Of interest in this connection is the observation that though the totally heterochromatic $\mathrm{Y}$ chromosome of $D$. viridis is as long as the $\mathrm{X}$, it participates in exchanges only half as frequently as the $\mathrm{X}$ (Baker, I949).

\footnotetext{
Acknowledgment.-We are grateful to Professor Mather for his comments on the script.
} 


\section{REFERENCES}

BAKER, W. K. 1949. The production of chromosome interchanges in Drosophila viridis. Genetics, 34, 167-193.

CATCheside, D. G., AND LEA, D. E. 1945. The rate of induction of dominant lethals in Drosophila melanogaster sperm by X-rays. F. Genet., 47, I-9.

FORD, C. E., POLANI, P. E., BRIGGS, J. H., AND BISHOP, P. M. F. 1959. A presumptive human XXY-XX mosaic. Nature, 183 , 1030-1032.

HERTWIG, P. 1938. Unterschiede in der Entwicklungsfahigkeit von $F_{1}$ Mausen nach Rontgenbestrahlung von Spermatogonien, fertigen und unfertigen Spermatozoen. Biol. Zentr., 58, 273-301.

JACOBS, P. A., AND STRONG, J. A. I959. A case of human intersexuality having a possibly XXY sex determining mechanism. Nature, 183, 302-303.

конN, н. I. 1960. The effect of paternal X-ray exposures on the secondary sex ratio in mice $\left(\mathrm{F}_{1}\right.$ generation). Genetics, $45,771-778$.

LAWRENCE, c. W. 1959. The effect of hybridity on chromosome behaviour. Ph.D. Thesis, Univ. of Birmingham.

RUSSELl, w. L. 1954. Genetic effects of radiation in mammals. Radiation Biology, Vol. I, Part 2, Ed. A. Hollaender. McGraw Hill.

SCHULL, w. J., AND NEEL, J. v. I958. Radiation and sex ratio in man. Science, I28, 343-348.

SWAMiNATHAN, M. S., AND MURTY, B. R. I959. Effect of X-radiation on pollen tube growth and seed setting in crosses between Nicotiana tabacum and $\mathcal{N}$. rustica. Z. fur Vererb., 9o, 393-399.

WESTERGAARD, M. 1958. The mechanism of sex determination in dioecious flowering plants. Adv. in Genetics, 9, 21 7-281. 